\title{
Requesting and Refusing Politeness Expression Teacher's Instruction in Teaching Learning Process
}

\author{
Bernieke Anggita Ristia Damanik ${ }^{1}$ \\ ${ }^{1}$ Doctoral Students English Applied Liguistics Program State University of Medan
}

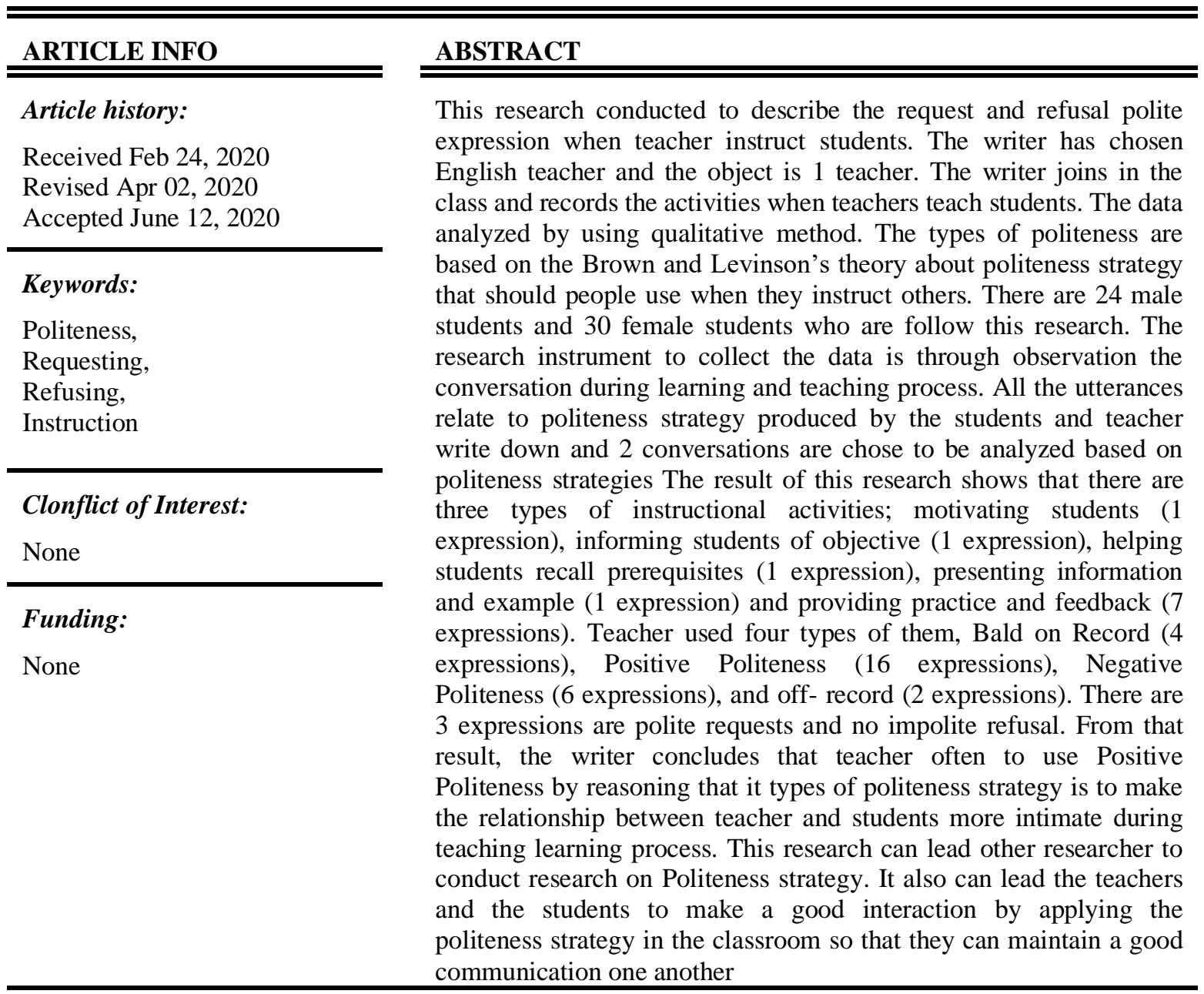

Corresponding Author: Bernieke Anggita Ristia Damanik, State University of Medan, Medan, Indonesia E-mail: berniekedamanik2016@gmail.com

Copyright $($ ) Association of Language Teachers in Southeast Asia. All rights reserved

\section{Introducation}

\subsection{Introduce the Problem}

To be polite or show respect is more crucial than the meaning of words together. Politeness strategies are significant concepts because to be successful in interaction, one has to conduct some important strategies to be polite. It can be used to generalize what kinds of politeness strategies would be used under what situations and see if individual and cultural differences would be found. An utterance which is considered polite in area, 
maybe considered as being impolite in another area as the standard of polite or impolite utterance is in every places, depends on the existence and standard norms or values in the area where the language comes from.

According to Brown and Levinson (1987:60), politeness relates to the psychological state, something that is emotionally invested and that can be lost, maintained, or enhanced, and must be constantly attended to in interaction. Yule (1996:119) defined politeness as showing awareness of and consideration for another person's face. One characteristic of politeness is hospitality. Hospitality is the act or practice of being hospitable. Hospitality brings about care and concern. This character is stronger and gives effect in that contact. Furthermore, it develops mental discipline to each person, mental discipline in their personality and attitude.

In language study, politeness refers to the teachers do when they converse with their students. Teacher is the main character in education, although education system does not make as the main focus, but the moral education still set teacher as the first model to follow. It relates with polite that instruct someone to do something as well. According to Mager (1984:50), Instructions has three components to be intent, such as behavior, conditions and criterion. The reason for investigating politeness is its importance in teaching and learning. Second language learners experience great differences in acquiring formulaic routines so that they can present themselves in situational appropriate ways. Most learners seek to be polite in the L2 or to be impolite, when necessary, in appropriate ways (Locastro, 1997: 23).

When the teacher talks about something, for a teacher request to students, sometimes he/she disappears thank, both of the polite words and the simple word which became a problem to some people. These words will change someone to respect one person to other. The teacher ought to be created education in learning process. The students will imitate what teacher's talks. From instructional, the students studied language, and it will be used not only in the course of study, but in real life in the out of school. Besides that, the politeness in refusing a request should be considered well, because it influences an uncomfortable feeling to someone. The sorry are needed in there. Mainly, in the class, it will construct a good communication between teacher and students. Moreover, learning having a goal to set up students becomes educated person with a good skill to express feeling accurate.

Otherwise, the function of face is important to the contribution of influencing the meaning of what someone's says, not except for student. It cannot deny that language is very global to make a fusion that will produce the new change. The language is very important not only to get a sign or act, but also to put up definite behaviors. In behavior, face and utterance are about the invention to build better interaction politely. In English teaching learning, politeness is very needed to build is created through the teacher's instruction. According to Licenciada (Rose and Kasper 2001: 8) that instructional will make a good intercede to build the acquisition of pragmatic ability. The teacher is the main role to teach students about it. Although every a difference in using it, in English, those words become important in communication.

In reference to the explanation has been shown above, this research is intended to find out the types of instructional activities used in requesting and refusing politeness expression Teacher's Instruction in English teaching learning process and the types of politeness strategies used in requesting and refusing expression teacher's Instruction in English teaching processes.

\section{Literature Review}

Theory of Politeness is the theory that accounts for the redressing of the affronts to face posed by face threatening acts to addresses. First formulated in 1987 by Penelope Brown and Stephen Levinson, politeness theory has since expanded academia's perception of politeness. Politeness is the expression of the speakers' intention to imitate face threats carried by certain face threatening acts toward another (Mills, 2003:6). The goal of politeness is to make all of the parties relaxed and comfortable with one another, these culturally defined standards at times may be manipulated to inflict shame on a designated party. Being polite therefore consists of attempting to save face for another.

There are some techniques to show politeness:

1. Expressing uncertainty and ambiguity through hedging and indirectness.

2. Polite lying.

3. Use of euphemisms ( which make use of ambiguity as well as connotation)

4. Preferring question tag to direct statements, such as "you were at the store, weren't you?"

In conversation, people can convey their own meaning by cooperating with the addressee. Indeed, misunderstandings happen somehow but most speakers and their interlocutors' are able to understand each other. People who obey the cooperative further the purpose of that conversation. Grice (1975:45) states the 
cooperative principle as follows: make sure your conversational contribution such as is required at the stage at which it occurs. The cooperative principle then can be divided into four maxims, called the Grecian Maxims:

a. Maxims of quantity: 1) Make your information as informative as required (for the current purposes of exchange), 2) Do not make your contribution more informative that is required.

b. Maxims of Quality: 1) Do not say what you believe to be false, 2) Do not for which you lack adequate evidence.

c. Maxims of Relevance: Be relevant.

d. Maxims of Manner: 1) Avoid obscurity of expression, 2) Avoid ambiguity, 3) Be brief, 4) Be orderly.

\subsection{The Politeness Maxim}

As mentioned before, for a successful conversation, the partners must achieve workable balance contributions. Speaker and hearer in rational conversation will cooperate in order to make each of their arms reached. The participants in talk exchange do not only give difference to cooperative principles as suggested by Grice (1975) but also politeness maxims. Leech (1993:3) states Grice's cooperative principle (1975) could not always answer why the participants in a talk exchange are more apt to use indirect way to convey their meaning, so as not to follow the maxim suggested in Grice's cooperative principle.

Leech thinks that politeness has a very important rule in a society, and it is needed to elaborate cooperative principle and also a completion of cooperative principle. To show the relation of politeness principle and the cooperative principle, Leech illustrates as follows (1993:121-122):

A: We'll all miss Bill and Agatha, won't we?

B: Well, we'll all miss Bill

In the dialogue, B has broken the rule of Grice's "cooperative principle" especially maxim of quantity as B does not mention Agatha in his talk. From this conversation, there is an implication that not all people will miss Agatha. Why B does not add "but we will not miss Agatha" in his talk is just for politeness reason, i.e. B wants to avoid impolite act toward third part (Agatha). So, it can be concluded that some information for B merely obeys politeness principle.

According to Leech (1993:123), there is a politeness principle with conversational maxims besides the cooperative principle that is needed in an interaction. He lists six maxims, such as: tact, generosity, approbation, modesty, agreement and sympathy. The first and second maxim, as do the third and the fourth one.

\subsubsection{The Tact Maxim}

The tact maxim states: "Minimize the expression of beliefs which imply cost to other; maximize the expression of beliefs which imply benefit to other". The first part of this maxim fits in with Brown and Levinson's negative politeness strategy of minimizing the imposition, and the second part reflects the positive politeness strategy of attending to the hearer's interests, wants and needs. "Could I interrupt you for a second?", "If I could just clarify this then"

\subsubsection{The Generosity Maxim}

Leech's Generosity maxim states: 'Minimize the expression of benefit to itself, maximize the expression of cost to self". Unlike the tact maxim, the maxim of generosity focuses on the speaker and says that others should be put first instead of it. "You relax and let me do the dishes. You must come and have dinner with us."

\subsubsection{The Approbation Maxim}

The approbation maxim states: "Minimize the expression of beliefs which express dispraise of other; maximize the expression of beliefs which express approval of other." It is preferred to praise others and if this impossible, to the issue, to give some sort of minimal response (possibly through the use of euphemisms), or to remain silent. The first part of the maxim avoids disagreement; the second part intends to make other feel good by showing solidarity."I heard you singing at the karaoke last night. It was, um... different Jhon, I know you're genius- would you know how to solve this math problem here?."

\subsubsection{The Modesty Maxim}

SALTeL Vol. 3, No. 2, 2020: $32-43$ 
The modesty maxim states: "minimize the expression of praise of it; maximize the expression of dispraise of it: "Oh, I'm stupid- I didn't make a note of our lecture! Did you?"

\subsubsection{The Agreement Maxim}

The agreement maxim runs as follows: "Minimize the expression of disagreement between self and other; maximize the expression of agreement between self and other." It is in line with Brown and Levinson's positive politeness strategies of: seek agreement" and "avoid disagreement", to which they attach great importance. However, it is not being claimed that people totally avoid disagreement. It is simply observed that they observed that they are much more direct in expressing agreement rather than disagreement.
A : I don't want my daughter to do this; I want to her to do that.
B : Yes, but ma'am, I thought we resolved this already on your last visit.

\subsubsection{The Sympathy Maxim}

The sympathy maxim states: "Minimize antipathy between self and other; maximize sympathy between self and other." This includes a small group of speech acts such as congratulation, commiseration and expressing condolences- all of which is in accordance with Brown and Levinson's positive politeness strategy of attending to the hearer's interest, wants and needs. "I was sorry to hear about your father"

\subsection{The Politeness Strategy}

According to Brown Levinson (1987:57), politeness strategies are developed to save the hearer's face. Face refers to the respect that an individual has or him or herself, and maintaining that "self-esteem" in public or in private situations. Brown and Levinson stated that there are two types of face in an interaction:

1. Negative face: the want of every 'competent adult member' that his actions can be unimpeded by others.

2. Positive face: the want of every member that his ways be desirable to at least some others.

In the model of Brown and Levinson's politeness, there are three critical sales a high to low rating politeness utterances. The three scales are determined by contextual, social and cultural which covers more the following scales:

1. Social distance between the speaker and the hearer

2. Contextual the speaker and hearer relative power

3. Cultural the degree of imposition with the required expenditure of goods or service.

\subsection{Brown and Levinson's Theory}

People show desire and speaker's want and awareness of another person's face (Yule, 1996: 60). Politeness is the way people speak or language style in daily interaction. Politeness strategies used to formulate messages in order to save the hearer's face when face-threatening acts are inevitable or desired. People use the same term to define a definition in turn-taking of conversation. These are the principal theories of politeness to make clear of the most common misunderstanding. Brown and Levinson (1987) outline four main types of politeness strategies are as follow: "bald on-record", positive politeness, negative politeness, and off-record (indirect).

\subsubsection{Bald-on record}

"Bald on record" strategy is as speaking in comfort with Grice maxims (Brown and Levinson, 1987: 94-95). Grice's maxims are used to be guidelines for achieving maximally efficient communication. In brief explanation as follows:

Maxim of quality: $\quad$ Be non-spurious (speak the truth, be sincere).

Maxim of quantity: $\quad$ (a) Don't say less than is required.

(b) Don't say more than is required.

Maxim of relevance $\quad$ : Be relevant.

Maxim of manner $\quad$ : Be perspicuous, avoid ambiguity and obscurity.

"Bald on-record" strategies usually do not attempt to minimize the threat to the hearer's face, although there are ways that bald on-record politeness can be used in trying to minimize face-threatening acts implicitly. Often using such a strategy will shock or embarrass the addressee, and so this strategy is most often utilized in situations where the speaker has a close relationship with the audience, such as family or close friends. Brown and Levinson outline various cases, in which one might use the bald on-record strategy, including: 


\subsubsection{Cases of non-minimization of the face threat}

1. Instances in which threat minimizing does not occur.

2. Great urgency or desperation. E.g.: Watch out!

3. Speaking as if great efficiency is necessary. E.g.: Hear me out!

4. Task-oriented. E.g.: Pass me the hammer.

5. Little or no desire to maintain someone's face. E.g.: Don't forget to clean the blinds!

\subsubsection{Cases of FTA-oriented bald-on record usage}

1. Doing the face-threatening act is in the interest of the hearer. E.g.: Your headlights are on!

2. Instances in which the threat is minimized implicitly.

3. Welcomes. E.g.: Come in!

4. Offers. E.g.: Leave it, I'll clean up later. Eat!

\subsubsection{Positive Politeness}

Positive politeness strategies seek to minimize the threat to the hearer's positive face. They are used to make the hearer feels good about himself, his interests or possessions, and are most usually used in situations where the audience knows each other fairly well. In addition to hedging and attempts to avoid conflict, some strategies of positive politeness include statements of friendship, solidarity, compliments.

\subsubsection{Negative Politeness}

Negative politeness strategies are oriented towards the hearer's negative face and emphasize avoidance on the hearer. These strategies presume that the speaker will be imposing on the listener and there is a higher potential for awkwardness or embarrassment than in bald on record strategies and positive politeness strategies. Negative face is the desire to remain autonomous so the speaker is more apt to include an out for the listener, through distancing styles like apologies.

\subsubsection{Off-Record (Indirect)}

The final politeness strategy outlined by Brown and Levinson is the indirect strategy; this strategy uses indirect language and removes the speaker from the potential to be imposing. For example, a speaker using the indirect strategy might merely say "wow, it's getting cold in here" insinuating that it would be nice if the listener would get up and turn up the thermostat without directly asking the listener to do so.

\subsection{Teaching and Learning}

\subsubsection{Teaching}

According to Smith (in Brown 1980:70), there are two operational definitions of teaching, such as:

a. Teaching is the action of a person to teach or the profession of a teacher

b. Teaching is the process in giving knowledge or skill

Based on Brown (1980: 77), teaching is guiding and facilitating learning, enabling the learner to learn, setting the conditions for learning.

\subsubsection{Learning}

\subsubsection{Definition of Learning}

Learning is the lifelong process of transforming information and experience into knowledge, skills, behaviors, and attitudes. Based on Brown (1980) as mention in Kimble and Garmezy (1963:133), Learning is a relatively permanent change in a behavioral tendency and is the result of reinforced practice

\subsubsection{Types of Learning}

According to Brown (1980) citing in Gagne (1965), there are several types of learning according to the context and subject matter, such as:

1) Signal

The individual learns to make a general diffuse response to a signal. This is the classical conditioned response of Pavlov.

2) Stimulus-response learning

The learner acquires a precise response to a discriminated stimulus.

3) Chaining 
What is acquired is a chain of two or more stimulus-response connections.

4) Verb association

Verbal association is the learning of chains that are verbal.

5) Multiple discrimination

The individual learns to make a number of different identifying responses to many different stimuli, which may resemble each other in physical appearance to a greater or lesser degree

6) Concept learning

The learner acquires the ability to make a common response to a class of stimuli even though the individual members of that class may differ widely from each other.

7) Principle learning

In term, a principle is a chain of two or more concepts.

8) Problem solving

Problem solving is a kind of learning that requires an internal event usually referred to as "thinking"

2.6 The Similarity and Difference of Teaching and Learning

Smith (1975: 63) says that the relationship between teaching and learning which is teaching is what teachers do and learning is what students do. Both of them will be tied in instruction. In addition, Smith also said that there is not necessarily a connection between teaching and learning. Some students can and will learn in spite of bad teaching and some students will not learn even with the best teaching.

\subsection{Teaching Instruction}

According to Reiser (1996) in Brown (1980:133), there are six types of Instructional

I.Motivating Students

Teacher sometimes cannot get really attention from students. It may teacher do not have enough ways to reach students such as:

1) Arousing students' curiosity

2) Making instruction relevant to students' interests

3) Entertaining students

4) Getting students to be involved actively in the lesson

5) Being enthusiastic

6) Providing students with rewards that may be tangible

II.Informing Students of Objectives

Give clear instruction to students through describing the outcomes of instruction may be sufficient. Students will be enthusiastic what they should do from teacher directions.

\section{III.Helping Students Recall Prerequisites}

Teachers should make students remember what necessary they will learn before they before get knowledge from there. It will make them enjoy following process to get new knowledge and skill.

IV.Presenting Information and Example

Teacher should give necessary information before he/she asks students some activities. It will make clear instruction so that students can do what the teacher wants as well.

V.Providing Practice and Feedback

Teacher teaches students not only theory but also practice. Students should have particular skill, knowledge or attitude. In getting some behavior like that, certainly they will do incorrect action. In this case, the duties to give feedback to correct what students have implemented. So teacher can correct the mistakes.

\section{VI.Summarizing the Lesson}

Teacher can conclude the lesson with summarize what students have learned. It is very important because students will remind the last subject. Teacher can start with simple terms, thus students will be easier to remember. 


\subsection{The Politeness in Requesting and Refusing}

When speaker wants other people to do something, it is a sense of request. In their communication, people need someone else to interact, such as request. On the other hand, in that transmission there is an opposition which is named refusing. Both of which are truly different, but have the same character to be expressed politely so between the speaker and the listener accept each other. Thus, there will be no misunderstanding among them.

To begin that expression to become polite, people can start with the words "please" and "thank". Those words are very simple but sometimes people neglect to use them when they request and refuse in the conversation. The sentence which the people pronounce will be softer to be heard. By using the words, it makes the listener more observe in the speaker's request. Additionally, when the listener refuses what the speaker wants, it will not make a gap.

There are some ways to make request become softer by using any sentence such as:

1. Past and continuous (e.g., I was hoping that/for ... .)

2. Modals

E.g. Could I (please) ... ? Would you (please) ... ?

Would you mind $(\mathrm{V}+$ ing $) \ldots$ ? - Would you mind helping me?

Could you possibly ... ? - Could you possibly help me out here?

Would you be as kind as to ... ? (Very polite) - Would you be so kind as to help me (with this)?

3. Embedding (e.g., I was wondering if . . it would be all right if ... ?)

4. Please + verb (more polite) - Please help me.

\section{Method}

\subsection{The Design of Research}

This research is used descriptive-qualitative methods. Isaac and Michael (1981: 46) the purpose of this method is to describe systematically the facts and characteristics of a given population or area of interest, factually and accurately. The writer will state about the politeness in requesting and refusing teachers' instruction in English Teaching Learning Process at Grade XI of SMAN 4 Pematangsiantar.

\subsection{The Subject of Research}

In this research, the writer takes the Grade XI IPS students of SMAN 4 Pematangsiantar as the participant, but the students are not the main focus because the writer only analyzes the teacher's instruction. Even though, students are still the main subjects in learning process, so that this research can be done. There is one teacher who follows this research and there are two classes in Grade XI IPS of SMAN 4 Pematangsiantar who follows this research such as XI IPS 3 and XI 4. Besides that, there are 24 male students and 30 female students who are follow this research.

\subsection{The Object of Research}

The object of study is Politeness in Requesting and Refusing Teacher's Instruction in English Teaching Learning Process

\subsection{Research Instrument}

To collect data is observation through the conversation during learning and teaching process. All the utterances relate to politeness strategy produced by the students and teacher written down and 2 conversations choses to be analyzed based on politeness strategies.

\subsection{The Technique of Collecting the Data}

There are some technique of collecting data in this research, such as :

1. Observes the class. The observation of the research which finds natural conversation in the school as primary data had been done at Grade XI of SMAN 4 Pematangsiantar

2. Records the teacher's utterances in classroom. The researcher records during 90 minutes for 2 times meeting at Grade XI IPS 3 and Grade XI IPS 4.

3.6 The Technique of Analyzing the Data 
1. Transcribing the utterances of teacher and students during the teaching learning process in to English.

2. Translating the utterances of teacher and students during the teaching learning process into English.

3. Classifying the data from the data which containing politeness strategy.

4. Describing the distribution of the use of politeness in dialogue.

5. Making conclusions from the data and giving suggestions.

\subsection{Triangulation}

In this research, the writer takes the Grade XI IPS students' of SMAN 4 Pematangsiantar as the participant, but the students are not the main focus because the writer only analyzes the teacher's instruction. Even though, students are still the main subjects in learning, so that this research can be done. The researcher used observation through conversation during learning and teaching process to collect the data. All the utterances relate to politeness strategy produced by the students and teacher written down and 2 conversations are chose to be analyzed based on the Brown and Levinson's theory that should people use when they instruct others..

\section{Results and Discussion}

\subsection{Result}

After analyzing the data, the writer gets some findings. The writer finds some types of instructional activities used in teaching learning process at Grade XI of SMAN 4 Pematangsiantar, that will be presented on the table below :

\begin{tabular}{|c|c|c|c|}
\hline NO & $\begin{array}{l}\text { INSTRUCTIONAL } \\
\text { ACTIVITIES }\end{array}$ & DATA 1 & DATA 2 \\
\hline a. & Motivating Students & & $\begin{array}{l}\text { This school is a favorite school, Isn't } \\
\text { right? So, try to speak English } \\
\text { organization meeting in this school }\end{array}$ \\
\hline b. & $\begin{array}{l}\text { Informing Students of } \\
\text { Objectives }\end{array}$ & & $\begin{array}{l}\text { 1) Teacher: Now open your book } \\
\text { pages } 8 \text { about asking and giving } \\
\text { opinion. Who knows the mean of } \\
\text { asking and giving opinion? } \\
\text { Students : Bertanya (how to ask and } \\
\text { give an opinion) }\end{array}$ \\
\hline c. & $\begin{array}{l}\text { Helping Students Recall } \\
\text { Prerequistes }\end{array}$ & & $\begin{array}{l}\text { 1) Okay, asking an opinion, opini itu } \\
\text { berarti pendapat. Segala sesuatu yang } \\
\text { akan kita utarakan kepada orang lain } \\
\text { adalah pendapat. (Okay, Asking an } \\
\text { opinion. Opinion is how to express } \\
\text { something.) }\end{array}$ \\
\hline d. & $\begin{array}{l}\text { Presenting Information } \\
\text { and Example }\end{array}$ & $\begin{array}{l}\text { 1) Yes, blaming is an expression } \\
\text { of using to blame something. } \\
\text { Look at here, example of page } \\
\text { six. Some example that how to } \\
\text { blame someone, that is how to } \\
\text { respond. Example "I'm sorry". }\end{array}$ & \\
\hline e. & $\begin{array}{lll}\text { Providing Practice and } \\
\text { Feedback }\end{array}$ & $\begin{array}{l}\text { 1) Teacher: Ya okay, after } \\
\text { your friend read the conversation, } \\
\text { what the conversation is about? } \\
\text { What is the conversation between } \\
\text { Jacky and Jeny about? What } \\
\text { they're talking about? Are they } \\
\text { talking about teeth? Yes about } \\
\text { teeth. } \\
\text { Students: No ... } \\
\text { Teacher: No? So about what? } \\
\text { What they are talking about? Are } \\
\text { they talking about foot? Ha? } \\
\text { Jacky and Jeny are talking about }\end{array}$ & $\begin{array}{l}\text { 1) Teacher: Ayo! siapa yang bisa } \\
\text { memberikan pertanyaan tentang } \\
\text { facebook? Angkat tangannya! (Let's } \\
\text { go! Who can give question about } \\
\text { facebook? Raise your hand!) } \\
\text { Student: What do you think about } \\
\text { facebook? } \\
\text { Teacher: Iya, what do you think about } \\
\text { facebook? Coba beri respon nya kakak } \\
\text { yang diujung! (Yes, what do you think } \\
\text { about facebook? Let's give the example } \\
\text { girl over there!) } \\
\text { Student : (One of students tries to }\end{array}$ \\
\hline
\end{tabular}




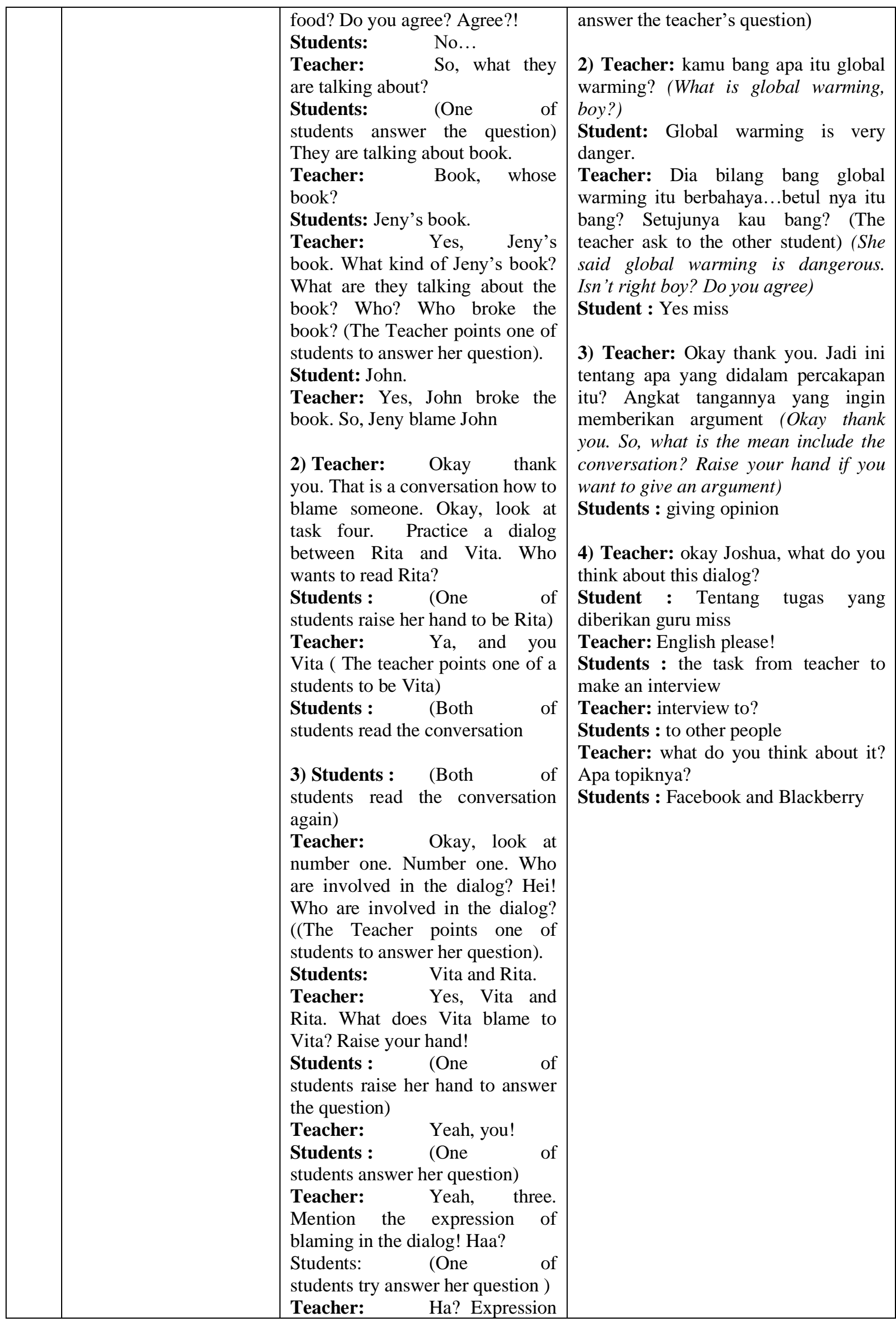




\begin{tabular}{|l|l|l|}
\hline & $\begin{array}{l}\text { of blaming? Is that expression of } \\
\text { blaming? I think it is response of } \\
\text { blaming. So what is expression of } \\
\text { blaming? You? } \\
\text { Students : (One of } \\
\text { students answer her question) } \\
\text { Teacher: } \quad \text { What is Vita's } \\
\text { response? } \\
\begin{array}{l}\text { Students : All of students } \\
\text { try to answer her question } \\
\text { together) }\end{array}\end{array} \mid$ \\
\hline
\end{tabular}

There are 28 utterances that used the types of politeness strategies which are collected from collecting data of SMAN 4 Pematangsiantar. There were some strategies of the types of politeness strategies found during doing research of SMAN 4 Pematangsiantar, they are :

a. Bald on Record : Imperative

b. Positive Politeness : Strategy 1 : Notice and attend to Hearer; Strategy 3 : Intensify interest to hearer ; Strategy 4 : Use in group identity markers ; Strategy 12: Include both of speaker and hearer in the activity ; Strategy 16 : Give gifts to hearer (good, sympathy, understanding, cooperation.

c. Negative Politeness : Strategy 1 :Be conventionally indirect ; Strategy 7 : Impersonalize Speaker and Hearer

d. Off Record : Strategy 1 : Give hints

After doing the research, the writer finds some requests are polite and there is no impolite request found during teaching learning process. The polite request expression will be presented on the table below:

Table 2. Polite Request

\begin{tabular}{|l|l|l|}
\hline NO & Polite Request Expression & Explanation \\
\hline 1 & $\begin{array}{l}\text { 1. Louder, please! } \\
\text { 2. English, please! } \\
\text { 3. Give your comment, please! }\end{array}$ & $\begin{array}{l}\text { In Brown and Levinson theory, please is the } \\
\text { character of negative politeness. In common theory } \\
\text { please is very polite to be said in the utterance. It } \\
\text { makes the hearer more respect to speaker }\end{array}$ \\
\hline
\end{tabular}

Each type of politeness strategies has different frequency:
a. Bald on Record: $14.29 \%$
b. Positive Politeness: $57.15 \%$
c. Negative Politeness: $21.42 \%$
d. Off Record: $7.14 \%$

The accumulation of politeness strategy used in teaching learning process at Grade XI of SMAN 4 Pematangsiantar

$$
\mathrm{N}=f / \mathrm{\eta} \times 100 \%
$$

$\mathrm{N} \quad=$ the percentage o the dominant each types politeness strategy

$f \quad=$ Frequency

$\mathrm{y} \quad=$ the total number of types politeness strategies

Table 3. Data Calculation

\begin{tabular}{|l|l|l|l|}
\hline No & The Types of Politeness Strategy & $F$ & X \\
\hline 1 & Bald on Record & 4 & $14.29 \%$ \\
\hline 2 & Positive Politeness & 16 & $57.15 \%$ \\
\hline 3 & Negative Politeness & 6 & $21.42 \%$ \\
\hline 4 & Bald off Record & 2 & $7.14 \%$ \\
\hline Total & 28 & 100 \\
\hline
\end{tabular}

Based on the research finding, the result of this research shows that politeness in requesting and refusing English teacher's instruction in learning process has three types of instructional activities; these are motivating students ( 1 expression), informing students of objective ( 1 expression), helping students recall prerequisites (1 expression), presenting information and example (1 expression) and providing practice and feedback ( 7 expressions). Teacher use four types of them, Bald on Record (4 expressions), Positive 
Politeness (16 expressions), Negative Politeness (6 expressions), and "off- record" (2 expressions). In addition, there are 3 expressions are polite request and there is no impolite refusal.

\subsubsection{Bald on Record}

Based on the analyzing, there are 7 dialogues that fit with the all maxims among them are data 1(Analysis data 1,5 and 8) and Data 2 (Analysis data 1)

4.1.2 Positive Politeness

Based on the analysis above, there are 16 dialogues that fit with Positive Politeness. They are data 1 (Analysis data 2 and 3) and Data 2 (Analysis Data 2, 3, 4, 5a, 5b, 6, 7, 11, 13, 15, 16, 17, 18, 19)

4.1.3 Negative Politeness

Based on the analysis above, there are 6 dialogues that fit with Negative Politeness. They are data 1 (Analysis data 6 and 7) and data 2 (Analysis data 9, 10, 12, 14)

4.1.4 Off Record

Based on the analysis above, there are 4 dialogues that fit with Off Record. They are data 1 (Analysis data 4) and data 2 (Analysis data 8).

4.1.5 Request and Refusal Expressions

There are 3 expressions polite requesting, Such as:1. Louder, please! 2. English, please! 3. Give your comment, please!

\section{Conclusuion and Suggestion}

After having analyzed above all the data, the writer describes some conclusions, such as:

1. Teacher uses five kinds of instructional activities in teaching learning process, such as :

a. Motivating Students

Teacher sometimes cannot get really attention from students. It may teacher do not have enough ways to reach students. That is why there are some strategies to teacher, such as: arousing students' curiosity, making instruction relevant to students' interests, entertaining students, getting students to be involved actively in the lesson. Being enthusiastic and providing students with rewards that may be tangible.

b. Informing Students of Objectives. It is to give clear instruction to students through describing the outcomes of instruction may be sufficient.

c. Helping Students Recall Prerequisites

Teachers should make students remember what necessary they will learn before they before get knowledge from there. It will make them enjoy to get new knowledge and skill.

d. Presenting Information and Example

Teacher should give necessary information before he/she asks students some activities. It will make clear instruction so that students can do what the teacher wants as well.

e. Providing Practice and Feedback

Teacher teaches students not only theory but also practice. Students should have particular skill, knowledge or attitude. In getting some behavior like that, certainly they will do incorrect action. In this case, duties to give feedback to correct what students have implemented. So teacher can correct the mistakes. Besides that, in giving feedback, it should think the type of feedback that appropriate to students.

2. Teacher uses four strategies of politeness in their instruction, namely "Bald on Record, Positive Politeness, Negative Politeness and Off Record". Every strategy emphasizes including the sense of effect.

3. The most dominant types of politeness strategy used in teaching learning is Positive Politeness.

4. The writer finds some requests are polite and there is no impolite request found during teaching learning process.

After finding the result of this research, the writer suggests that the findings might become a reference for teachers while teaching. They will know more about politeness in the requesting and refusing in English Teaching Learning. Every utterance which is teacher says will be a reference for their students to be imitated. Teacher should more understand the theory to be the better teacher so that students can take example. Then, student should understand and realize that the politeness is very important in making a good communication

\section{References}

Brown, H. Douglas. 1980. Principles of Language Learning and Teaching. New Jersey: Prentice-Hall 
Brown P, Levinson S. 1987. Universals in language usage: politeness phenomena. In Goody E (ed.)

Driscoll, M.P. 1994. Psychology of Learning Instruction. Boston: Allyn and Bacon

Gagne, Robert M. 1965. The Conditions of Learning. New York: Holt, Rinehart and Winston

Grice, H.P. 1975, “Logic and Conversation”, Syntax and Semantics, Speech Act, 3. New York: AcademyPress

Kasper and Rose,K.R. 2001. Pragmatics in Language Teaching. New York: Cambridge University Press

Kimble, Gregory A and Garmezy,Norman. 1963. Principles of General Psychology (2 $2^{\text {nd }}$ ed). New York : The Ronald Press

Leech G, 1993. Principles of pragmatics. London: Longman

Locastro, Virginia.1997. Politeness and Pragmatic Competence in Foreign Language Education . Language Teaching Research 1:239-269

Mager, R.F. 1984. Preparing Instructional Objectives $\left(2^{\text {nd }}\right.$ ed). Belmont, CA: Fearon-Pitman

Mills, Sara. 2003. Gender and Politeness, Cambridge : Cambridge University Press

Smith, Frank. 1975. Comprehension and Learning : A Conceptual Learner

for Teachers. New York : Holt, Rinehart and Winston

Wijana, I Dewa Putu. 1996. Dasar-dasar Pragmatik. Yogyakarta. Penerbit Andi

Yule, G. 1996. Pragmatics. New York: Oxford University Press 